\title{
The Study of Escherichia coli Proteases. Intracellular Serine Protease of E. coli - an Analogue of Bacillus Proteases
}

\author{
By ALEXANDER YA. STRONGIN, DMITRII I. GORODETSKY \\ AND VALENTIN M. STEPANOV \\ Institute of Genetics and Selection of Industrial Microorganisms, \\ Dorojnaya 8, 113545 Moscow, U.S.S.R.
}

(Received 4 July 1978)

\begin{abstract}
Two serine proteases in extracts of Escherichia coli grown to stationary phase were purified to homogeneity using affinity chromatography on gramicidin S-Sepharose 4B. One enzyme was closely related to, if not identical with, the 'trypsin-like' protease II of $E$. coli. The other was capable of cleaving the subtilisin chromogenic substrate $N$-carbobenzoxy-L-alanyl-Lalanyl-L-leucine-p-nitroanilide and resembled the intracellular serine proteases of Bacillus spp. The amino acid composition of this E. coli protease was similar to that of the Bacillus licheniformis enzyme. These data indicate a relationship between proteolytic enzymes of evolutionary distant Gram-negative Enterobacteriaceae and Gram-positive spore-forming Bacillus.
\end{abstract}

\section{INTRODUCTION}

The existence of proteolytic activity within bacterial cells has been known for many years, but few studies of purified bacterial intracellular proteases have appeared in the literature. Intracellular serine proteases have been extracted and purified to homogeneity from sporulating cells of certain Bacillus species, namely Bacillus subtilis, strains A-50 and Marburg 168 (Stepanov et al., 1977 a; Strongin et al., 1978 a; Strongin et al., 1978c), Bacillus thuringiensis var. berliner (Lecadet et al., 1977) and Bacillus licheniformis (Strongin et al., $1979 b$ ). The amino acid composition, $N$-terminal sequence [homologous with those of extracellular serine proteases, the subtilisins, of Bacillus spp. (Strongin et al., 1978 b)], cellular distribution (Stepanov et al., 1977b; Strongin et al., 1979a), involvement in protein turnover and spore-coat processing (Cheng \& Aronson, $1977 a, b$ ), specific action on RNA polymerase (Lecadet et al., 1977) and some other properties and functions were reported. Comparable data are lacking for Enterobacteriaceae proteases, and so the possible relationship between the intracellular serine proteases of these distant bacterial species remains uncertain. Although Escherichia coli is the most extensively studied bacterial species, present knowledge of its proteolytic system is also rather limited. The scarcity of biochemical data on the purified $E$. coli enzymes is caused by difficulties in their isolation, the extremely low concentration within the cells and the absence of specific affinity adsorbents suitable for the simultaneous isolation of several proteases. 'Chymotrypsin-like' protease I (Pacaud \& Uriel, 1971; Pacaud et al., 1976) and 'trypsin-like' protease II (Pacaud \& Richaud, 1975; Pacaud, $1976)$ are the only endopeptidases of $E$. coli to have been purified and studied in some detail.

In the present paper we report the isolation of $E$. coli intracellular serine proteases applying the same approach for their purification as previously employed for proteases from Bacillus spp. (Strongin et al., 1978a). The main purification step used was affinity chromatography 
on Sepharose $4 \mathrm{~B}$ containing covalently bound cyclopeptide antibiotic gramicidin S (Izotova et al., 1978). This adsorbent was satisfactory for the isolation of at least two distinct $E$. coli intracellular serine proteases in high yields and of sufficient purity for their preliminary enzymological characterization and comparison with the Bacillus enzymes.

\section{METHODS}

Materials. Analytical grade reagents were used throughout this work. EDTA, EGTA, diisopropylffuorophosphate, phenylmethylsulphonyl fluoride and $N$-benzoyl-DL-arginine- $p$-nitroanilide (Bz-L-Arg- $p$ NA) were purchased from Serva; DEAE-cellulose DE52 was from Whatman; Sepharose 4B was from Pharmacia. $N$-Carbobenzoxy-L-alanyl-L-alanyl-L-leucine-p-nitroanilide (Z-L-Ala-L-Ala-L-Leu- $p N A$ ) was synthesized in our laboratory by Dr L. A. Lyublinskaya as described earlier (Lyublinskaya et al., 1974, 1977). The affinity adsorbent gramicidin S-Sepharose 4B was prepared according to Strongin et al. (1978a); as judged by amino acid analysis, it contained $1 \mu \mathrm{mol}$ ligand per $\mathrm{ml}$ wet adsorbent. Enzymes and proteins were obtained from Serva, except subtilisin BPN' (trade name Nagarse) was from Nagase, Japan, and Streptomyces subtilisin protein inhibitor IT-Aj1 (Ikenaka et al., 1974) was isolated from Actinomyces janthinus and kindly provided by Dr D. N. Chermensky (Institute of Biochemistry and Physiology of Microorganisms, Academy of Science of the USSR, Poustchino, Moscow Region).

Organism. Escherichia coli $\mathrm{K} 12$ strain W3350 $\left(\mathrm{gal}^{-} \mathrm{B} 1^{-}\right)$, bearing plasmid RSF2124 that determines penicillin resistance, was used. Cultures were grown for $18 \mathrm{~h}$ at $37^{\circ} \mathrm{C}$ in a 1001 fermenter containing 751 of $\mathrm{M} 9$ minimal medium (comprising $6 \mathrm{~g} \mathrm{Na}_{2} \mathrm{HPO}_{4}, 3 \mathrm{~g} \mathrm{KH}_{2} \mathrm{PO}_{4}, 0.5 \mathrm{~g} \mathrm{NaCl}, 1 \mathrm{~g} \mathrm{NH}_{4} \mathrm{Cl}$ and $0.1 \mathrm{~g} \mathrm{MgSO}_{4}$, per litre) supplemented with $10 \%(\mathrm{v} / \mathrm{v})$ Hottinger broth, $0.8 \%(\mathrm{w} / \mathrm{v})$ glucose and $100 \mu \mathrm{g}$ penicillin $\mathrm{ml}^{-1}$. Stationary phase cells were harvested by centrifugation and frozen at $-20^{\circ} \mathrm{C}$ until use.

Assay of serine protease. Activity was assayed spectrophotometrically at $410 \mathrm{~nm}$ with Bz-L-Arg-pNA or Z-L-Ala-L-Ala-L-Leu- $p \mathrm{NA}$ as the substrate. Reactions were carried out at $40{ }^{\circ} \mathrm{C}$ in $50 \mathrm{mM}$-Tris/HCl buffer, $\mathrm{pH} 8.5$, containing $1 \mathrm{~mm}-\mathrm{CaCl}_{2}$ (buffer A). The reaction mixture contained $2.5 \mathrm{ml}$ of Bz-L-Arg-pNA (0.435 $\mathrm{mg} \mathrm{ml}{ }^{-1}$ in buffer A supplemented with $2 \%$ dimethylformamide) and 10 to $100 \mu 1$ of the enzyme preparation, or $1.25 \mathrm{ml}$ of buffer A, $0.25 \mathrm{ml}$ of Z-L-Ala-L-Ala-L-Leu- $p \mathrm{NA}\left(0.5 \mathrm{mg} \mathrm{ml}^{-1}\right.$ in dimethylformamide) and 10 to $100 \mu \mathrm{l}$ of the enzyme preparation. One unit of activity is defined as the amount of enzyme liberating $1 \mu \mathrm{mol}$ $p$-nitroaniline $\mathrm{min}^{-1}$ from the substrate under the conditions specified above, using $\epsilon=89001 \mathrm{~mol}^{-1} \mathrm{~cm}^{-1}$ for $p$-nitroaniline in all calculations. Protein concentration was calculated from the absorbance at $280 \mathrm{~nm}$.

Acrylamide gel electrophoresis. Electrophoresis was performed in 7.5 and $10 \%(\mathrm{w} / \mathrm{v})$ acrylamide gels (acrylamide/ $N, N^{\prime}$-methylenebisacrylamide, 19:1) as described by Davis (1964). The mobility $\left(R_{F}\right)$ of protein bands was determined relative to bromophenol blue. Proteins were stained with $0 \cdot 1 \%(\mathrm{w} / \mathrm{v})$ Coomassie Brilliant Blue R-250 (Serva) in $7.5 \%$ (v/v) acetic acid.

Isolation of the enzymes. All procedures were carried out at $4{ }^{\circ} \mathrm{C}$, unless stated otherwise. Activity was assayed with both $p$-nitroanilide substrates throughout the purification. All buffers used contained $1 \mathrm{~mm}$ $\mathrm{CaCl}_{2}$ except those for acrylamide gel electrophoresis.

Cells ( $150 \mathrm{~g}$ wet $\mathrm{wt})$ were thawed, resuspended in buffer $\mathrm{A}$ and ultrasonically disrupted in a $150 \mathrm{~W}$ MSE sonifier. The homogenate (about $1 \mathrm{l}$ ) was centrifuged at $30000 \mathrm{~g}$ for $60 \mathrm{~min}$, and to the supernatant (crude cell extract) $10 \%$ streptomycin sulphate solution was added to give a final concentration of $1 \%$. After several hours at $0{ }^{\circ} \mathrm{C}$ the precipitated nucleic acids were removed by centrifugation $(30000 \mathrm{~g}, 30 \mathrm{~min})$. The supernatant was then treated with solid ammonium sulphate, and the fraction precipitated between $0 \cdot 35$ and 0.75 saturation was collected by centrifugation $(30000 \mathrm{~g}, 60 \mathrm{~min})$, dialysed against buffer A overnight and applied to a DEAE-cellulose DE52 column $(5 \times 25 \mathrm{~cm})$ equilibrated with buffer A. The column was eluted with 21 of buffer A, followed by $600 \mathrm{ml}$ of a Tris/HCl buffer linear gradient (50 to $500 \mathrm{~mm}, \mathrm{pH} 8 \cdot 5$ ). The active fractions (Fig. 1) were pooled, dialysed against buffer A and loaded on to a gramicidin S-Sepharose 4B column $(2 \times 45 \mathrm{~cm})$. The proteins were eluted stepwise with 11 of buffer A, $300 \mathrm{ml}$ of buffer A containing $1 \mathrm{M}-\mathrm{NaCl}$ and $200 \mathrm{ml}$ of buffer A containing $1 \mathrm{M}-\mathrm{NaCl}$ and $25 \%$ 2-propanol (Fig. 2). The fractions active against Bz-L-Arg- $p$ NA and Z-L-Ala-L-Ala-L-Leu- $p$ NA were pooled separately and dialysed against buffer A. After concentration by ultrafiltration through a UM-2 Diaflo membrane in a $10 \mathrm{ml}$ Amicon cell, they were subjected to acrylamide gel electrophoresis. For these runs, $6 \times 100 \mathrm{~mm}$ tubes with $7.5 \%$ gel loaded with $1 \mathrm{mg}$ protein were used, and electrophoresis was carried out at $0^{\circ} \mathrm{C}$ in Tris/glycine buffer, pH 8.3 (Davis, 1964). The protein bands possessing protease activity were visualized in ultraviolet light after incubating gels in Bz-L-Arg- $p$ NA or Z-L-Ala-L-Ala-L-Leu- $p$ NA solutions as described previously (Lyublinskaya et al., 1974; Strongin et al., 1976). The bands were cut out, and the proteins were extracted from the crushed gel with buffer A containing $100 \mathrm{~mm}-\mathrm{NaCl}$ overnight. Gel particles were removed by filtration through a sintered glass no. 4 filter, and the filtrates were dialysed against buffer $\mathrm{A}$ and concentrated by ultrafiltration as above. 


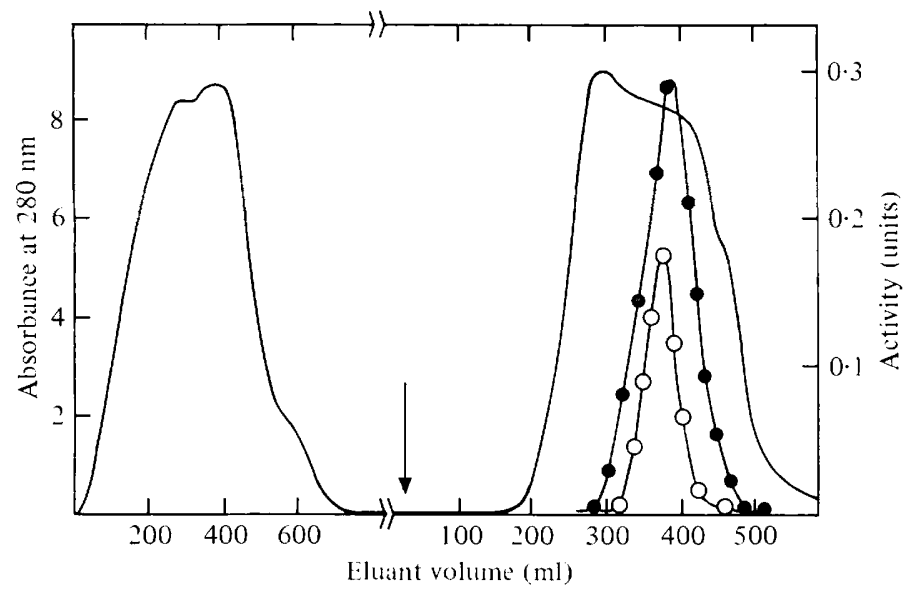

Fig. 1. Chromatography of proteases on DEAE-cellulose DE52. Dialysed enzyme preparation obtained after ammonium sulphate fractionation was applied to a DEAE-cellulose column $(5 \times 25$ $\mathrm{cm}$ ) equilibrated with buffer A. Fractions of $10 \mathrm{ml}$ were collected at a flow rate of $50 \mathrm{ml} \mathrm{h}^{-1}$. The arrow indicates the beginning of a $600 \mathrm{ml}$ linear gradient of 50 to $500 \mathrm{~mm}$-Tris/ $\mathrm{HCl}$ buffer, $\mathrm{pH} 8.5$, containing $1 \mathrm{~mm}-\mathrm{Ca}^{2+}$. - Absorbance at $280 \mathrm{~nm}$; $\mathrm{O}$, activity with $\mathrm{Bz}-\mathrm{L}-\mathrm{Arg}-\mathrm{pNA}$; , activity with Z-L-Ala-L-Ala-L-Leu- $p$ NA.

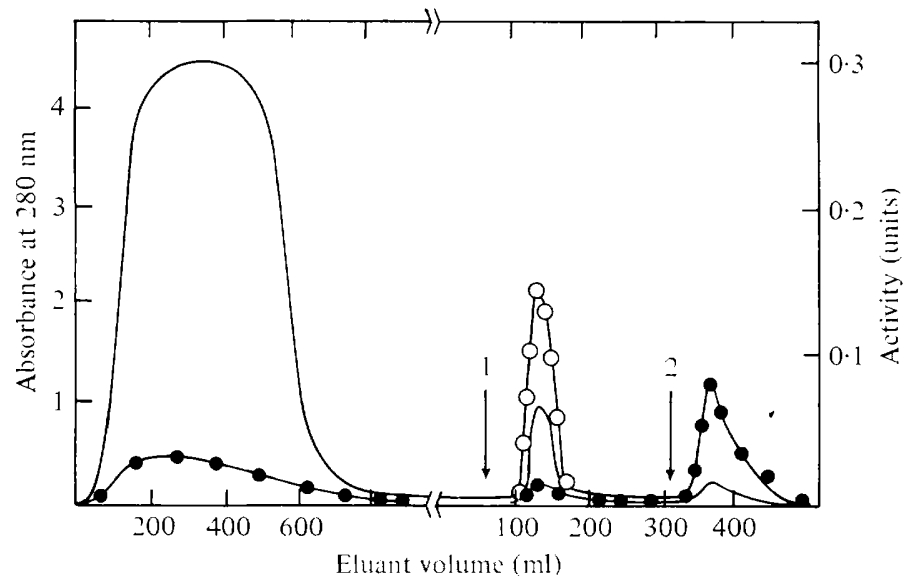

Fig. 2. Chromatography of proteases on gramicidin S-Sepharose 4B. Dialysed enzyme preparation obtained after DEAE-cellulose chromatography was applied to an affinity column $(2 \times 45 \mathrm{~cm})$ equilibrated in buffer A. Fractions of $5 \mathrm{ml}$ were collected at a flow rate of $40 \mathrm{ml} \mathrm{h}^{-1}$. The first arrow indicates the beginning of elution with buffer A containing $1 \mathrm{M}-\mathrm{NaCl}$; the second arrow indicates the beginning of elution with buffer A containing $1 \mathrm{~m}-\mathrm{NaCl}$ and $25 \% 2$-propanol. - , Absorbance at $280 \mathrm{~nm} ; \bigcirc$, activity with Bz-L-Arg- $p$ NA;, , activity with Z-L-Ala-L-Ala-L-Leu- $p$ NA.

Amino acid analysis. Before amino acid analysis, the enzyme samples were inactivated with 1 mm-diisopropylfluorophosphate for $60 \mathrm{~min}$ at $20^{\circ} \mathrm{C}$, extensively dialysed against water, freeze-dried and hydrolysed with $5.7 \mathrm{M}-\mathrm{HCl}$ in the sealed tubes in vacuo for $24 \mathrm{~h}$ at $110^{\circ} \mathrm{C}$. The amino acid composition of the hydrolysates was determined using a Durrum D500 amino acid analyser.

Gel filtration. The molecular weight of the enzymes was estimated by Sephadex G-100 gel filtration according to Andrews (1964). A column $(1.5 \times 150 \mathrm{~cm})$ was run in buffer A containing $100 \mathrm{~mm}-\mathrm{NaCl}$ at a flow rate of $6 \mathrm{ml} \mathrm{h}^{-1}$; fractions of $2 \mathrm{ml}$ were collected and assayed for enzyme activity. 
Table 1. Purification of serine proteases ISP-A-Eco and ISP-L-Eco from extracts of E. coli grown to stationary phase

\begin{tabular}{|c|c|c|c|c|c|}
\hline Purification step & $\begin{array}{l}\text { Protein } \\
(\mathrm{mg})\end{array}$ & $\begin{array}{l}\text { Total } \\
\text { activity* } \\
\text { (units) }\end{array}$ & $\begin{array}{l}\text { Specific } \\
\text { activity } \\
\text { (units } \mathrm{mg}^{-1} \text { ) }\end{array}$ & $\begin{array}{r}\text { Yield } \\
(\%)\end{array}$ & $\begin{array}{l}\text { Purification } \\
\text { factor }\end{array}$ \\
\hline $\begin{array}{l}\text { Crude cell extract } \\
\text { ISP-A-Eco } \\
\text { Z-I-Ala-L-Ala-L-Leu- } \\
p \text { NA-cleaving activity } \dagger\end{array}$ & - & 26 & - & 100 & - \\
\hline $\begin{array}{l}\text { Streptomycin sulphate } \\
\text { ISP-A-Eco } \\
\text { Z-L-Ala-L-Ala-L-Leu- } \\
\text { pNA-cleaving activity }\end{array}$ & 15000 & 25 & 0.00165 & 96 & 1 \\
\hline $\begin{array}{l}\text { Ammonium sulphate } \\
\text { ISP-A-Eco } \\
\text { Z-L-Ala-L-Ala-L-Leu- } \\
p \text { NA-cleaving activity }\end{array}$ & 10000 & $\begin{array}{l}24 \\
7 \cdot 5\end{array}$ & $\begin{array}{l}0.0024 \\
0 \cdot 00075\end{array}$ & 92 & $\begin{array}{l}1 \cdot 45 \\
1.5\end{array}$ \\
\hline $\begin{array}{l}\text { DEAE-cellulose DE52 } \\
\text { ISP-A-Eco } \\
\text { Z-L-Ala-L-Ala-L-Leu- } \\
\text { pNA-cleaving activity }\end{array}$ & 1700 & $21 \cdot 5$ & 0.0126 & 83 & $\begin{array}{l}7 \cdot 5 \\
8 \cdot 0\end{array}$ \\
\hline $\begin{array}{l}\text { Affinity chromatography o } \\
\text { gramicidin S-Sepharose } 4 \\
\text { ISP-A-Eco } \\
\text { ISP-L-Eco }\end{array}$ & $\begin{array}{r}16 \\
6\end{array}$ & $\begin{array}{r}13.0 \\
1.6\end{array}$ & $\begin{array}{l}0 \cdot 81 \\
0 \cdot 14\end{array}$ & $\begin{array}{l}50 \\
20\end{array}$ & $\begin{array}{l}490 \\
280\end{array}$ \\
\hline $\begin{array}{l}\text { Acrylamide gel } \\
\text { electrophoresis } \ddagger \\
\text { ISP-A-Eco } \\
\text { ISP-L-Eco }\end{array}$ & $\begin{array}{l}0 \cdot 17 \\
0.20\end{array}$ & $\begin{array}{l}1 \cdot 3 \\
0 \cdot 28\end{array}$ & $\begin{array}{l}7 \cdot 5 \\
1.4\end{array}$ & $\begin{array}{l}5 \\
3 \cdot 5\end{array}$ & $\begin{array}{l}4550 \\
2800\end{array}$ \\
\hline
\end{tabular}

* Activity of ISP-A-Eco was determined with Bz-L-Arg- $p$ NA and ISP-L-Eco with Z-L-Ala-L-Ala-L-Leu$p \mathrm{NA}$ as substrates.

$\dagger$ Indicated as Z-L-Ala-L-Ala-L-Leu- $p$ NA-cleaving activity since up to the affinity chromatography step this activity was due to at least two proteases.

‡ At the last preparation step there was a marked inactivation of ISP-A-Eco, presumably due to autolysis. A similar, but not so pronounced, effect was observed for ISP-L-Eco.

\section{RESULTS}

\section{Isolation of two E. coli intracellular proteases}

Extracts of $E$. coli contained two types of proteolytic activity, one active with the subtilisin chromogenic substrate Z-L-Ala-L-Ala-L-Leu- $p$ NA and the other capable of hydrolysing the trypsin chromogenic substrate Bz-L-Arg- $p$ NA. The activity towards Z-L-Ala-L-Ala-L-Leu$p$ NA was due to at least two enzymes (see below) and was two orders of magnitude lower than the corresponding activity in crude extracts of B. subtilis A-50 (Strongin et al., 1978a). The activity towards Bz-L-Arg-pNA behaved as a single protease and was termed intracellular protease-A-Eco (ISP-A-Eco).

Activities towards both substrates were purified from the crude cell extracts of $E$. coli. A key step in the purification procedure was affinity chromatography on gramicidin SSepharose 4B. ISP-A-Eco was retained on this adsorbent and was quantitatively eluted as the ionic strength of the eluting buffer was increased by adding $1 \mathrm{M}-\mathrm{NaCl}$ (Fig. 2). About $80 \%$ of the total activity with Z-L-Ala-L-Ala-L-Leu- $p$ NA passed freely through the affinity column. The remaining $20 \%$ of the total Z-L-Ala-L-Ala-L-Leu- $p$ NA-cleaving activity applied to the column was tightly bound to the adsorbent and required high ionic strength plus $25 \%$ 2-propanol for elution (Fig. 2). This activity was termed intracellular proteaseL-Eco (ISP-L-Eco). Since the capacity of the column was sufficient to bind the total amount of Z-L-Ala-L-Ala-L-Leu- $p$ NA-cleaving activity applied, it seems that $E$. coli possesses at 


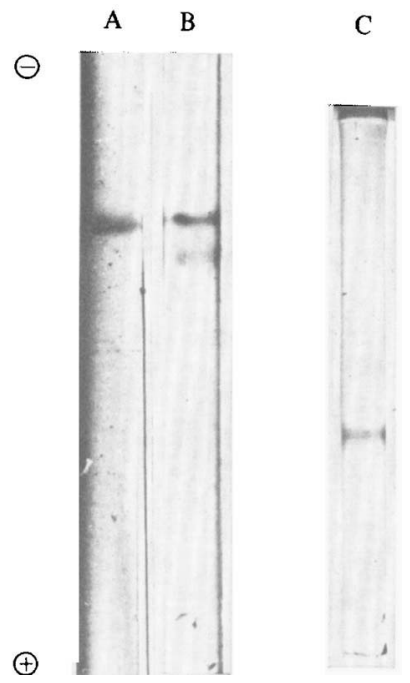

Fig. 3. Acrylamide gel electrophoresis pattern of purified proteases ISP-A-Eco and ISP-L-Eco. A, Freshly prepared ISP-A-Eco; B, ISP-A-Eco after $3 \mathrm{~d}$ storage in buffer A at $4{ }^{\circ} \mathrm{C}$; C, ISP-L-Eco. The samples (20 to $30 \mu \mathrm{g}$ ) were run in $7.5 \%$ acrylamide gels; migration was from top to bottom.

least two proteases active against this substrate. Only the activity which was tightly bound to gramicidin S-Sepharose 4B was studied further.

Pacaud et al. (1976) found that $E$. coli contained protease I, an enzyme capable of cleaving $p$-nitrophenyl esters of $N$-substituted amino acids and possessing a chymotrypsinlike' substrate specificity. It may well be that this enzyme could cleave Z-L-Ala-L-Ala-L-Leu$p$ NA and possibly the activity towards this substrate that did not bind to gramicidin $\mathrm{S}-$ Sepharose 4B was protease I.

After the affinity chromatography step in the purification procedure, ISP-A-Eco and ISP-L-Eco appeared to be about $10 \%$ pure, as judged by acrylamide gel electrophoresis followed by protein staining with Coomassie Brilliant Blue. The bands corresponding to ISP-A-Eco and ISP-L-Eco were visualized by incubating half of the gel in the corresponding chromogenic substrate solution.

The final purification of the enzymes was achieved by acrylamide gel electrophoresis and resulted in electrophoretically pure preparations of ISP-A-Eco and ISP-L-Eco (Fig. 3). The purification procedure is summarized in Table 1.

\section{Properties of ISP-A-Eco}

The enzyme had an approximately 10-fold higher specific activity than commercially available trypsin with Bz-L-Arg- $p$ NA (a commonly used trypsin substrate) but was completely inactive with Z-L-Ala-L-Ala-L-Leu- $p$ NA, a substrate specific for subtilisins and 'subtilisinlike' intracellular serine proteases of Bacillus spp. (Strongin et al., 1978a). When incubated with $1 \mathrm{~mm}$-diisopropylfluorophosphate in buffer A for $60 \mathrm{~min}$ at $20^{\circ} \mathrm{C}$, ISP-A-Eco was completely inactivated, whereas under comparable conditions $1 \mathrm{~mm}$-phenylmethylsulphonyl fluoride (another common serine protease inhibitor) was without any inhibitory effect. Similar behaviour has been reported for proteases I and II of $E$. coli and for acetylcholinesterase (Pacaud \& Uriel, 1971; Pacaud \& Richaud, 1975).

Chelating agents [EDTA and EGTA $(5 \mathrm{~mm})$ ] and a 50 -fold excess of soybean trypsin inhibitor did not affect the activity of ISP-A-Eco. In contrast, subtilisin protein inhibitor IT-Aj1 in a 30 to 50-fold molar excess inhibited ISP-A-Eco completely. 
Table 2. Properties of intracellular serine proteases of E. coli and $B$. subtilis A-50

The properties of protease I of E. coli are from Pacaud \& Uriel (1971) and Pacaud et al. (1976), protease II of $E$. coli from Pacaud \& Richaud (1975) and intracellular serine protease of B. subtilis A-50 (ISP-Bsu A-50) from Strongin et al. (1978a).

\begin{tabular}{|c|c|c|c|c|c|}
\hline Property & $\begin{array}{l}\text { Protease } \\
\text { I }\end{array}$ & $\begin{array}{l}\text { Protease } \\
\text { II }\end{array}$ & ISP-A-Eco & ISP-L-Eco & $\begin{array}{c}\text { ISP-Bsu } \\
\text { A-50 }\end{array}$ \\
\hline Activity with Bz-L-Arg-pNA* & 0 & $14 \cdot 1$ & $7 \cdot 5$ & 0 & 0 \\
\hline Activity with Z-L-Ala-L-Ala-L-Leu- $p$ NA* & - & - & 0 & $1 \cdot 4$ & 18 \\
\hline $\begin{array}{l}\text { Percentage of activity retained after } \\
\text { treatment with: }\end{array}$ & & & & & \\
\hline Diisopropylfluorophosphate & 0 & 0 & 0 & $\mathbf{0}$ & 0 \\
\hline Phenylmethylsulphonyl fluoride & 100 & 100 & 100 & 0 & 0 \\
\hline EDTA & 100 & 100 & 100 & 0 & 0 \\
\hline Soybean trypsin inhibitor & 100 & 100 & 100 & 100 & 100 \\
\hline Subtilisin inhibitor IT-Aj1 & - & - & 0 & 0 & 0 \\
\hline $\begin{array}{l}\text { Electrophoretic mobility in } 7.5 \% \\
\text { acrylamide gel } \dagger\end{array}$ & - & - & $0 \cdot 4$ & $0 \cdot 7$ & 0.7 \\
\hline $\begin{array}{l}\text { Molecular weight } \\
\text { From Sephadex G-100 gel filtration in } \\
\text { the presence of } 0 \cdot 1 \mathrm{M} \mathrm{NaCl} \text { or } \mathrm{KCl} \\
\text { From SDS-gel electrophoresis }\end{array}$ & $\begin{array}{l}43000 \\
21000\end{array}$ & $\begin{array}{l}75000 \\
60000 \ddagger\end{array}$ & 75000 & $\begin{array}{c}55000 \\
-\end{array}$ & $\begin{array}{l}55000 \\
30000\end{array}$ \\
\hline Stability in buffer at $4^{\circ} \mathrm{C} \S$ & $\mathrm{S}$ & $\mathrm{U}$ & $\mathrm{U}$ & $\mathrm{S}$ & $\mathrm{S}$ \\
\hline
\end{tabular}

The molecular weight of the protease estimated by Sephadex G-100 gel filtration in buffer A containing $100 \mathrm{~mm}-\mathrm{NaCl}, \mathrm{pH} 8 \cdot 5$, was $75000 \pm 2000$.

The enzyme was unstable in buffer $\mathrm{A}$ at $4{ }^{\circ} \mathrm{C}$ and was degraded over several days, presumably due to autolysis. Only fresh preparations of the enzyme gave a single protein band $\left(R_{F} 0.4\right)$ when subjected to electrophoresis in $7.5 \%$ acrylamide gels. After storage in buffer A at $4{ }^{\circ} \mathrm{C}$, a second rather diffuse band $\left(R_{F}\right.$ near 0.45$)$ appeared in the protease preparation (Fig. 3). The properties of the enzyme are summarized in Table 2.

The most characteristic feature of the amino acid composition of ISP-A-Eco was the high content of dicarboxylic amino acids, especially Glx (Table 3). It also contained rather high concentrations of Lys, Leu, Phe and Arg and low concentrations of Val and Ala. Based on the amino acid composition, a minimum molecular weight of approximately 30000 was calculated (Table 3), a value in agreement with those for intracellular serine proteases from Bacillus spp. (Strongin et al., 1978a).

\section{Properties of ISP-L-Eco}

This enzyme was clearly different from ISP-A-Eco in several respects. No activity was observed with the trypsin substrate Bz-L-Arg- $p$ NA, but Z-L-Ala-L-Ala-L-Leu- $p$ NA was rapidly hydrolysed. Its activity against the latter substrate was similar to that of subtilisin

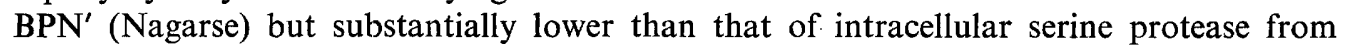
B. subtilis A-50 (Strongin et al., 1978a). The enzyme was completely inactivated by $1 \mathrm{~mm}-$ diisopropylfluorophosphate, $1 \mathrm{~mm}$-phenylmethylsulphonyl fluoride and by 2 mM-EDTA or EGTA (a consequence of a strict $\mathrm{Ca}^{2+}$-dependence). In addition, the enzyme was completely inhibited in the presence of a 3 to 5 -fold molar excess of subtilisin protein inhibitor IT-Aj1, but was not inhibited by a 50 -fold molar excess of soybean trypsin inhibitor. ISP-L-Eco was stable when stored in buffer $\mathrm{A}$ at $4{ }^{\circ} \mathrm{C}$ for several weeks. 
Table 3. Amino acid composition of intracellular serine proteases of E. coli, $B$. subtilis and B. licheniformis

The amino acid composition of protease I of $E$. coli is from Pacaud et al. (1976), intracellular serine protease of $B$. subtilis 168 (ISP-Bsu 168) from Strongin et al. (1979a), intracellular serine protease of $B$. subtilis A-50 (ISP-Bsu A-50) from Strongin et al. (1978a) and intracellular serine protease of $B$. licheniformis 1001 (ISP-Bli) from Strongin et al. (1979b). For each enzyme, the analytical data show the percentage composition $(b)$ and the nearest integer values calculated from the molecular weight $(a)$. The molecular weights of the ISP-A-Eco and ISP-L-Eco polypeptide chains were assumed to be about 30000 , to allow ready comparison of their composition with the Bacillus enzymes.

\begin{tabular}{|c|c|c|c|c|c|c|c|c|c|c|c|c|}
\hline \multirow{2}{*}{$\begin{array}{l}\text { Amino } \\
\text { acid }\end{array}$} & \multicolumn{2}{|c|}{ Protease I } & \multicolumn{2}{|c|}{ ISP-A-Eco } & \multicolumn{2}{|c|}{ ISP-L-Eco } & \multicolumn{2}{|c|}{ ISP-Bli } & \multicolumn{2}{|c|}{$\begin{array}{c}\text { ISP- } B s u \\
168\end{array}$} & \multicolumn{2}{|c|}{$\begin{array}{c}\text { ISP-Bsu } \\
\mathrm{A}-50\end{array}$} \\
\hline & $a$ & $b$ & $a$ & $b$ & $a$ & $b$ & $a$ & $b$ & $a$ & $b$ & $a$ & $b$ \\
\hline Lys & 12 & $7 \cdot 1$ & 14 & $4 \cdot 7$ & 13 & $4 \cdot 5$ & 12 & $4 \cdot 0$ & 17 & $5 \cdot 8$ & 20 & $6 \cdot 8$ \\
\hline His & 2 & $1 \cdot 2$ & 7 & $2 \cdot 4$ & 10 & $3 \cdot 55$ & 10 & $3 \cdot 4$ & 10 & $3 \cdot 4$ & 6 & $2 \cdot 0$ \\
\hline Arg & 10 & $5 \cdot 9$ & 14 & $4 \cdot 7$ & 7 & $2 \cdot 4$ & 5 & $1 \cdot 7$ & 6 & $2 \cdot 0$ & 6 & $2 \cdot 0$ \\
\hline Asx & 18 & $10 \cdot 7$ & 30 & $10 \cdot 1$ & 27 & $9 \cdot 3$ & 33 & $11 \cdot 1$ & 36 & $12 \cdot 1$ & 36 & $12 \cdot 1$ \\
\hline Thr & 4 & $2 \cdot 0$ & 14 & $4 \cdot 7$ & 14 & $4 \cdot 7$ & 13 & $4 \cdot 4$ & 13 & $4 \cdot 4$ & 13 & $4 \cdot 4$ \\
\hline Ser & 11 & $6 \cdot 5$ & 24 & $8 \cdot 1$ & 40 & $13 \cdot 6$ & 34 & $11 \cdot 5$ & 23 & $7 \cdot 8$ & 25 & $8 \cdot 4$ \\
\hline Glx & 21 & $12 \cdot 4$ & 40 & $13 \cdot 5$ & 43 & $14 \cdot 7$ & 42 & $14 \cdot 2$ & 38 & $12 \cdot 8$ & 33 & $11 \cdot 1$ \\
\hline Pro & 9 & $5 \cdot 3$ & 13 & $4 \cdot 4$ & 13 & $4 \cdot 5$ & 13 & $4 \cdot 4$ & 13 & $4 \cdot 4$ & 13 & $4 \cdot 4$ \\
\hline Gly & 11 & $6 \cdot 5$ & 39 & $13 \cdot 1$ & 36 & $12 \cdot 4$ & 42 & $14 \cdot 0$ & 40 & $13 \cdot 5$ & 36 & $12 \cdot 2$ \\
\hline Ala & 13 & $7 \cdot 7$ & 26 & $8 \cdot 8$ & 30 & $10 \cdot 6$ & 28 & $9 \cdot 5$ & 26 & $8 \cdot 8$ & 32 & $10 \cdot 8$ \\
\hline Val & 17 & $10 \cdot 0$ & 15 & $5 \cdot 1$ & 12 & $4 \cdot 15$ & 15 & $5 \cdot 1$ & 19 & $6 \cdot 4$ & 19 & $6 \cdot 4$ \\
\hline Met & 4 & $2 \cdot 4$ & 7 & $2 \cdot 35$ & ND & ND & 5 & $1 \cdot 7$ & 5 & $1 \cdot 7$ & 5 & $1 \cdot 7$ \\
\hline Ile & 10 & 5.9 & 12 & $4 \cdot 0$ & 9 & $3 \cdot 1$ & 11 & $3 \cdot 7$ & 13 & $4 \cdot 4$ & 13 & $4 \cdot 4$ \\
\hline Leu & 15 & 8.9 & 23 & $7 \cdot 8$ & 20 & 6.9 & 19 & $6 \cdot 4$ & 22 & $7 \cdot 4$ & 25 & $8 \cdot 4$ \\
\hline Tyr & 6 & $3 \cdot 6$ & 7 & $2 \cdot 35$ & 6 & $2 \cdot 05$ & 6 & $2 \cdot 0$ & 7 & $2 \cdot 35$ & 7 & $2 \cdot 35$ \\
\hline Phe & 6 & $3 \cdot 6$ & 12 & $4 \cdot 0$ & 10 & $3 \cdot 55$ & 8 & $2 \cdot 7$ & 8 & $2 \cdot 7$ & 7 & $2 \cdot 35$ \\
\hline Total & 169 & 100 & 297 & 100 & 290 & 100 & 296 & 100 & 296 & 100 & 296 & 100 \\
\hline
\end{tabular}

The molecular weight of the native enzyme was $55000 \pm 2000$ in buffer A containing 100 $\mathrm{mm}-\mathrm{NaCl}, \mathrm{pH} 8 \cdot 5$, when measured by gel filtration in Sephadex G-100. Electrophoresis in $7 \cdot 5 \%$ acrylamide gel showed ISP-L-Eco to have a high electrophoretic mobility $\left(R_{F}\right.$ near 0.7) (see Fig. 3 and Table 2).

The amino acid composition of ISP-L-Eco was characterized by high concentrations of Glx, Lys, Leu, Phe and Ser and low concentrations of Val and Ala (Table 3). Based on amino acid analysis, a minimum molecular weight of about 30000 was calculated. Native protease I of $E$. coli has been reported to be a dimer of molecular weight 43000 , and 21000 under denaturing conditions. Serine proteases of Bacillus spp. have also been found as dimers (Strongin et al., 1978a). Presumably, ISP-L-Eco might also form a dimer having a molecular weight of about 55000 .

\section{DISCUSSION}

Although the two isolated intracellular proteases are both serine proteases, they are nevertheless quite distinct, having different stabilities, electrophoretic mobilities, substrate specificity and responses to various inhibitors. Furthermore, ISP-L-Eco had a strict dependence on $\mathrm{Ca}^{2+}$, whereas ISP-A-Eco was independent of $\mathrm{Ca}^{2+}$. The two proteases could also be distinguished by their amino acid compositions.

Of the two serine proteases found by Pacaud et al. (1976) in E. coli strain B, the 'trypsinlike' protease II was similar in properties to ISP-A-Eco, suggesting that protease II and ISP-A-Eco are closely related, if not identical. Our second $E$. coli protease, ISP-L-Eco, was quite distinct from the previously described proteases I and II of E. coli (Pacaud \& Uriel, 
1971; Pacaud et al., 1976; Pacaud \& Richaud, 1975) but had similar properties to the protease from $B$. subtilis A-50. In amino acid composition, ISP-L-Eco was similar to the enzymes from B. subtilis A-50, B. subtilis 168 and, particularly, B. licheniformis 1001 . To our knowledge this is the first indication of a relationship between proteolytic enzymes of evolutionary distant bacterial species, namely Gram-negative Enterobacteriaceae and Grampositive spore-forming Bacillus.

Thus, cultures of $E$. coli contain at least three intracellular serine proteases: protease I (Pacaud et al., 1976), protease II (Pacaud \& Richaud, 1975) (corresponding to ISP-A-Eco according to our nomenclature) and ISP-L-Eco. Indeed three bands of activity with acetylphenylalanine naphthyl ester as substrate were previously seen after gel electrophoresis of crude cell extracts of E. coli (Pacaud \& Uriel, 1971) and Salmonella typhimurium (Miller et al., 1976). Presumably, the three enzymes corresponding to these bands have now been purified. Nevertheless, it should be stressed that components involved in the protein degradation system in bacteria (deg system) were not precisely identified. Degradation of E. coli $\beta$-galactosidase fragments in S. typhimurium mutants lacking proteases I and II was not impaired, suggesting that these serine proteases are not directly involved in the deg system (Miller \& Zipser, 1977). It is tempting to suppose that ISP-L-Eco, by analogy with the intracellular serine proteases in Bacillus spp. which are involved in protein processing and turnover (Hageman \& Carlton, 1973; Szulmajster \& Keryer, 1975; Cheng \& Aronson, $1977 a, b)$, might be a component of the deg system of Enterobacteriaceae.

We wish to thank Dr N. K. Yankovsky for the generous gift of the E. coli strain and Dr V. Moshentsova for her help with the fermenter. Excellent technical assistance of I. A. Kuznetsova is gratefully acknowledged.

\section{REFERENCES}

ANDREwS, P. (1964). Estimation of the molecular weight of proteins by Sephadex gel-filtration. Biochemical Journal 91, 222-233.

Cheng, Y. \& Aronson, A. I. (1977a). Alterations of spore coat processing and protein turnover in a Bacillus cereus mutant with a defective postexponential intracellular protease. Proceedings of the National Academy of Sciences of the United States of America 74, 1254-1258.

Cheng, Y. \& Aronson, A. I. (1977b). Characterization and functions of intracellular proteases in sporulating Bacillus cereus. Archives of Microbiology 115, 61-66.

Davis, B. J. (1964). Disc electrophoresis. II. Method and application to human serum proteins. Annals of the New York Academy of Sciences 121, 404427.

Hageman, J. H. \& Carlton, B. C. (1973). Effects of mutational loss of specific intracellular proteases on the sporulation of Bacillus subtilis. Journal of Bacteriology 114, 612-617.

Ikenaka, T., Odani, S., Sakai, M., Nabeshima, Y., Sato, S. \& Murao, S. (1974). Amino acid sequence of an alkaline proteinase inhibitor (Streptomyces Subtilisin Inhibitor) from Streptomyces albogriseolus S-3253. Journal of Biochemistry 76, 11911209.

Izotova, L. S., Gorodetsky, D. I., YanONis, V. V., Baratova, L. A., Belyanova, L. P., Timokhina, E. A., Strongin, A. YA. \& Stepanov, V. M. (1978). Isolation of Bacillus subtilis intracellular serine protease by Gramicidin S-Sepharose 4B affinity chromatography. Bioorganicheskaya Khimiya 4, 397-403 (in Russian).

Lecadet, M.-M., Lescourret, M. \& Kller, A. (1977). Characterization of an intracellular protease isolated from Bacillus thuringiensis sporulating cells and able to modify homologous RNA polymerase. European Journal of Biochemistry 79, 329-338.

Lyublinskaya, L. A., Belyaev, S. V., Strongin, A. Ya., Matyash, L. F., Levin, E. D. \& Stepanov, V. M. (1974). A new chromogenic substrate for subtilisin. Analytical Biochemistry 62, 371-376.

Lyublinskaya, L. A., Yakusheva, L. D. \& StepANOV, V. M. (1977). Synthesis of subtilisin peptide substrates and their analogs. Bioorganicheskaya Khimiya 3, 273-279 (in Russian).

Miller, C. G. \& ZiPSER, D. (1977). Degradation of Escherichia coli $\beta$-galactosidase fragments in protease-deficient mutants of Salmonella typhimurium. Journal of Bacteriology 130, 347-353.

Miller, C. G., Heiman, C. \& Yen, C. (1976). Mutants of Salmonella typhimurium deficient in an endoprotease. Journal of Bacteriology 127, 490497.

Pacaud, M. (1976). Purification of protease II from Escherichia coli by affinity chromatography and separation of two enzyme species from cells harvested at late log phase. European Journal of Biochemistry 64, 199-204.

Pacaud, M. \& Richaud, C. (1975). Protease II 
from Escherichia coli. Purification and characterization. Journal of Biological Chemistry 250, 7771-7779.

PACAUD, M. \& URIEL, J. (1971). Isolation and some properties of a proteolytic enzyme from Escherichia coli (protease 1). European Journal of Biochemistry 23, 435-442.

Pacaud, M., Sibilli, L. \& Le Bras, G. (1976). Protease I from Escherichia coli. Some physicochemical properties and substrate specificity. European Journal of Biochemistry 69, 141-151.

Stepanov, V. M., Strongin, A. Ya., Izotova, L. S., Abramov, Z. T., Lyublinskaya, L. A., Ermakova, L. M., Baratova, L. A. \& Belyanova, L. P. (1977a). Intracellular serine protease from Bacillus subtilis. Structural comparison with extracellular serine proteases-subtilisins. Biochemical and Biophysical Research Communications 77, 298-305.

Stepanov, V. M., Strongin, A. Ya., Izotova, L. S. \& Abramov, Z. T. (1977b). Intracellular proteinase of Bacillus subtilis. Acta biologica et medica germanica 36, 1509-1514.

Strongin, A. Ya., Azarenkova, N. M., Vaganova, T. I., Levin, E. D. \& Stepanov, V. M. (1976). Visualization of leucineaminopeptidase activity after acrylamide gel electrophoresis. Analytical Biochemistry 74, 597-599.

Strongin, A. Ya., Izotova, L. S., Abramov, Z. T., Gorodetsky, D. I., ERMAKova, L. M., Baratova, L. A., Belyanova, L. P. \& Stepanov, V. M. $(1978 a)$. Intracellular serine protease of Bacillus subtilis: sequence homology with extracellular subtilisins. Journal of Bacteriology 133, 14011411.
Strongin, A. Ys., Izotova, L. S., Abramov, Z. T., Gorodetsky, D. I. \& Stepanov, V. M. (1978b). Two related structural genes coding two homologous serine proteases in the Bacillus subtilis genome. Molecular and General Genetics 159, 337-339.

Strongin, A. Ya., Izotova, L. S., Abramov, Z. T., Gorodetsky, D. I., Ermakova, L. M. \& StepANOV, V.M. $(1978 c)$. On the appearance of Bacillus subtilis intracellular serine protease in the cell membrane and culture medium. Comparison of the enzyme with other Bacillus subtilis serine proteases. Archives of Microbiology (in the Press). Strongin, A. YA., Gorodetsky, D. I., Kuznetsova, I. A., Abramov, Z. T., Yanonis, V. V., Belyanova, L. P., Baratova, L. A. \& Stepanov, V. M. (1979a). Intracellular serine proteinase of Bacillus subtilis strain Marburg 168. Comparison with the homologous enzyme from Bacillus subtilis strain A-50. Biochemical Journal (in the Press).

Strongin, A. Ya, Abramov, Z. T., Yaroslantseva, N. G., Baratova, L. A., Belyanova, L. P. \& Stepanov, V. M. (1979b). Direct comparison of the subtilisin-like intracellular protease of Bacillus licheniformis with the homologous enzymes of Bacillus subtilis. Journal of Bacteriology (in the Press).

Szulmajster, J. \& Keryer, E. (1975). Isolation and properties of thermosensitive sporulation mutants of Bacillus subtilis deficient in intracellular protease activity. In Spores VI, pp. 271-278. Edited by P. Gerhardt, H. L. Sadoff \& R. W. Costilow. Washington, D.C.: American Society for Microbiology. 